\title{
Cost-effectiveness of Osimertinib in activating epidermal growth factor receptor gene (EGFR)- mutations in first-line for advanced non-small cell lung cancer
}

\author{
Jacopo Giuliani, Andrea Bonetti \\ Department of Oncology, Mater Salutis Hospital - Az. ULSS 9 Scaligera, Legnago (VR) 1-37045, Italy. \\ Correspondence to: Dr. Jacopo Giuliani, Department of Oncology, Mater Salutis Hospital - Az. ULSS 9 Scaligera, Via Gianella, \\ Legnago (VR) 1-37045, Italy. E-mail: giuliani.jacopo@alice.it \\ How to cite this article: Giuliani J, Bonetti A. Cost-effectiveness of Osimertinib in activating epidermal growth factor receptor \\ gene (EGFR)-mutations in first-line for advanced non-small cell lung cancer. Cancer Drug Resist 2021;4:740-4. \\ https://dx.doi.org/10.20517/cdr.2021.14
}

Received: 14 Feb 2021 First Decision: 30 Mar 2021 Revised: 7 Apr 2021 Accepted: 12 Apr 2021 Available online: 27 Apr 2021

Academic Editors: Godefridus J. Peters, Iwao Ojima Copy Editor: Xi-Jun Chen Production Editor: Xi-Jun Chen

Keywords: NSCLC, activating EGFR-mutations, first-line treatment, TKIs, cost of drugs

The introduction of first- or second-generation epidermal growth factor receptor gene (EGFR) tyrosine kinase inhibitors (TKIs) in chemonaive patients with advanced non-small cell lung cancer (NSCLC) has radically changed the treatment in this molecular subgroup, with an improvement in progression-free survival (PFS) compared to standard chemotherapy ${ }^{[1]}$. The introduction of these active new agents is associated with a relevant increase of costs, and the most fitting example is represented by the recent introduction of osimertinib in this setting. In fact, the topic of costs has become preponderant in oncology and radiotherapy, as well as in relation to the introduction of target biological agents and immunotherapy, with their greatest budgetary impact ${ }^{[2]}$. Recently, Aguilar-Serra et al.$^{[3]}$ performed a cost-effectiveness analysis of osimertinib vs. standard first-line TKIs (erlotinib and gefitinib) in advanced NSCLC. They concluded that osimertinib was more effective in terms of quality-adjusted life-years (QALYs) gained than comparators (erlotinib-gefitinib), but a discount greater than $60 \%$ in osimertinib acquisition cost would be required to obtain a cost-effective alternative. 
Table 1. Cost of drugs

\begin{tabular}{ll}
\hline Drug & Pharmacy cost ( $\boldsymbol{\epsilon})$ (dose) \\
\hline Gemcitabine & $9.90(1000 \mathrm{mg})$ \\
Paclitaxel & $6.19(100 \mathrm{mg})$ \\
Docetaxel & $9.84(80 \mathrm{mg})$ \\
Carboplatin & $7.18(150 \mathrm{mg})$ \\
Cisplatin & $8.80(50 \mathrm{mg})$ \\
Vinorelbine & $6.54(10 \mathrm{mg})$ \\
Nab-paclitaxel & $214.48(100 \mathrm{mg})$ \\
Bevacizumab & $2004.61(1 \mathrm{administration} \mathrm{at} 7.5 \mathrm{mg} \mathrm{pro} \mathrm{Kg})$ \\
& $2672.28(1 \mathrm{administration} \mathrm{at} 15.0 \mathrm{mg}$ pro $\mathrm{Kg})$ \\
Pemetrexed & $226.65(100 \mathrm{mg})$ \\
Pembrolizumab & $2056.08(100 \mathrm{mg})$ \\
Erlotinib & $45.80(150 \mathrm{mg}$ tablet $)$ \\
Gefitinib & $72.06(250 \mathrm{mg}$ tablet $)$ \\
Afatinib & $65.85(20 \mathrm{mg}$ tablet $)$ \\
Osimertinib & $145.28(80 \mathrm{mg}$ tablet $)$ \\
\hline
\end{tabular}

The aim of our study was to assess the pharmacological costs of TKIs (erlotinib, gefitinib, afatinib and osimertinib) in patients with activating EGFR mutations in first-line treatment for advanced NSCLC. Pivotal phase III randomized controlled trials (RCTs) were considered. The last available update of each trial was considered as the original source. The deadline for trial publication and/or presentation was 30 June 2020. Incremental cost-effectiveness ratio (ICER) was calculated as the ratio between the difference of the costs in the intervention and in the control groups (pharmacy costs) and the difference between the effect in the intervention and in the control groups [overall survival (OS)]. The costs of drugs were based on those at the pharmacy of our hospital and are expressed in euros $(€)$, updated to June 2020. The pharmacy costs of drugs are summarized on Table 1 . The dosages of drugs were considered according to those reported in each RCT. The European Society for Medical Oncology Magnitude of Clinical Benefit Scale (ESMO-MCBS) was applied the to the pivotal $\mathrm{RCTs}^{[4]}$ to derive a relative ranking of clinical benefit ${ }^{[5]}$. All data were reviewed by two investigators (Giuliani J and Bonetti A) and separately computed by two investigators (Giuliani J and Bonetti A).

Nine phase III RCTs ${ }^{[6-14]}$, including 2291 patients, were considered. The OS of TKIs ranged from 18.8 months for gefitinib in the IPASS trial ${ }^{[8,15]}$ to 38.6 months in the FLAURA trial ${ }^{[14,16]}$. ESMO-MCBS reached Grade 4 for OPTIMAL trial ${ }^{[6]}$, EURTAC trial $^{\left[{ }^{[7]}\right.}$, IPASS trial ${ }^{[8]}$, LUX-Lung 3 trial ${ }^{[12]}$ and FLAURA trial ${ }^{[14]}$; Grade 3 for NEJ2002 trial ${ }^{[9]}$, WJTOG3405 trial ${ }^{[10]}$ and LUX-Lung $6^{[13]}$; and Grade 1 for First-SIGNAL trial ${ }^{[11]}$. The lowest cost for 1 month of OS gain was associated with osimertinib, at $€ 9740$ per month OS gained [Table 2].

Two main variables influence pharmacy costs: the efficacy of treatment and the price of drugs. The first variable is related to the patient's inclusions criteria, and we know that results from RCTs might not be representative of daily clinical practice (i.e., of patients treated outside such trials). The price of drugs is the second strong variable. In fact, there may be a cost standardization problem within different European countries (in Italy, there are no significant pharmacy cost differences among the different regions), due to the use of local pharmacy cost. Another limit is related to the consideration of only direct costs (which account for about $55 \%$ of total medical expenses). In Europe, expenditure for cancer drugs amounted to $€ 10$ billion in 2005, increasing more than three times to $€ 32$ billion in $2018^{[17]}$. In this scenario, European countries negotiate the price of new drugs with the manufacturers with the aim to obtain a discount, so as to 
Table 2. Pharmacological costs and difference in OS with the different treatment regimens of the pivotal phase III RCTs in first-line treatment for advanced NSCLC with activating EGFR mutations

\begin{tabular}{|c|c|c|c|c|c|c|c|c|c|}
\hline Ref./Trial & Comparative regimens & $\begin{array}{l}N \text { of } \\
\text { patients }\end{array}$ & $\begin{array}{l}\text { OS } \\
\text { (months) }\end{array}$ & $\begin{array}{l}P \text { - } \\
\text { value }\end{array}$ & $\begin{array}{l}\text { Difference in OS } \\
\text { (months) }\end{array}$ & $\begin{array}{l}\text { Median duration of treatment } \\
\text { (months) }\end{array}$ & $\begin{array}{l}\text { Costs of } \\
\text { therapy }(€)\end{array}$ & $\begin{array}{l}\text { Difference in } \\
\text { costs }(€)\end{array}$ & ICER (€) \\
\hline \multirow{2}{*}{$\begin{array}{l}\text { Zhou et al. } \\
\text { OPTIMAL }\end{array}$} & Carboplatin + gemcitabine & 72 & $27.2^{\mathrm{a}}$ & $N S^{a}$ & -4.4 & 2.4 & 246 & 17,576 & NA \\
\hline & Erlotinib & 82 & $22.8^{\mathrm{a}}$ & & & 12.8 & 17,822 & & \\
\hline \multirow[t]{2}{*}{$\begin{array}{l}\text { Rosell et al. } \\
\text { EURTAC }\end{array}$} & $\begin{array}{l}\text { Cisplatin }+ \\
\text { docetaxel/gemcitabine }\end{array}$ & 87 & $22.1^{b}$ & $N S^{b}$ & 0.8 & 2.8 & $238-222$ & $11,179-11,195$ & $\begin{array}{l}13,974- \\
13,994\end{array}$ \\
\hline & Erlotinib & 86 & $22.9^{\mathrm{b}}$ & & & 8.2 & 11,417 & & \\
\hline \multirow{2}{*}{$\begin{array}{l}\text { Mok et al. } \\
\text { IPASS }\end{array}$} & Carboplatin + paclitaxel & 129 & $17.4^{c}$ & $N S^{c}$ & 1.4 & 3.4 & 202 & 13,818 & 9870 \\
\hline & Gefitinib & 132 & $18.8^{c}$ & & & 6.4 & 14,020 & & \\
\hline \multirow{2}{*}{$\begin{array}{l}\text { Maemondo et al. }{ }^{[9]} \\
\text { NEJ2002 }\end{array}$} & Carboplatin + paclitaxel & 110 & $26.6^{d}$ & $N S^{d}$ & 1.1 & 2.8 & 202 & 21,923 & 19,930 \\
\hline & Gefitinib & 114 & $27.7^{\mathrm{d}}$ & & & 10.1 & 22,125 & & \\
\hline \multirow{2}{*}{$\begin{array}{l}\text { Mitsudomi et al. }{ }^{[10]} \\
\text { WJTOG3405 }\end{array}$} & Cisplatin + docetaxel & 86 & $37.3^{\mathrm{e}}$ & $N S^{e}$ & -2.4 & 2.1 & 238 & 11,591 & NA \\
\hline & Gefitinib & 86 & $34.9^{\mathrm{e}}$ & & & 5.4 & 11,829 & & \\
\hline \multirow{2}{*}{$\begin{array}{l}\text { Han et al. }{ }^{[11]} \\
\text { First-SIGNAL }\end{array}$} & Cisplatin + gemcitabine & 26 & 22.9 & NS & -0.6 & 4.1 & 334 & 11,799 & NA \\
\hline & Gefitinib & 22 & 22.3 & & & 5.4 & 11,829 & & \\
\hline \multirow{2}{*}{$\begin{array}{l}\text { Sequist et al. }{ }^{[12]} \\
\text { LUX-Lung } 3\end{array}$} & Cisplatin + pemetrexed & 111 & $28.2^{\dagger}$ & $N S^{f}$ & 0.0 & 4.1 & 13,051 & 30,989 & NA \\
\hline & Afatinib & 229 & $28.2^{f}$ & & & 11.0 & 44,040 & & \\
\hline \multirow{2}{*}{$\begin{array}{l}\text { Wu et al. }{ }^{[13]} \\
\text { LUX-Lung } 6\end{array}$} & Cisplatin + gemcitabine & 122 & $23.5^{f}$ & $N S^{f}$ & -0.4 & 2.9 & 238 & 52,210 & NA \\
\hline & Afatinib & 242 & $23.1^{\dagger}$ & & & 13.1 & 52,448 & & \\
\hline \multirow{2}{*}{$\begin{array}{l}\text { Soria et al. }{ }^{[14]} \\
\text { FLAURA }\end{array}$} & Standard EGFR-TKI ${ }^{g}$ & 277 & $31.8^{\mathrm{h}}$ & $0.046^{h}$ & 6.8 & 11.5 & $16,012-25,192$ & $66,230-75,410$ & 9740- \\
\hline & Osimertinib & 279 & $38.6^{h}$ & & & 20.7 & 91,422 & & 11,090 \\
\hline
\end{tabular}

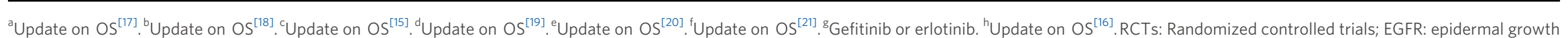
factor receptor; NSCLC: non-small cell lung cancer; N: number; OS: overall survival; ICER: incremental cost-effectiveness ratio [expressed as the difference ( $€$ ) per month - OS gained]; NS: not significant; NA: not applicable.

allow more patients to be treated. This results in "confidential rebates" (i.e., not publicly available), which may hamper access to drugs with a consequent overpayment without improving the value of drugs. The extraordinary costs of novel treatments may form a new type of resistance, costs resistance. In several countries, this may preclude treatments with these compounds.

There are several published articles, mostly in China, regarding this topic. However, to our knowledge, this is the first cost-effectiveness analysis of TKIs in patients with activating EGFR-mutations in first-line treatment for advanced NSCLC in Europe. 
In addition, the annual cost of drugs treatment ( $€ 116,880$ for osimertinib, $€ 118,840$ for gefitinib and $€$ 165,528 for erlotinib) are not in line with those reported in the literature, which indicate implementing intervention for thresholds of less than $\$ 61,500(€ 57,138)$ per life-year gained ${ }^{[18]}$.

We also compared the pharmacy costs of TKIs (osimertinib, erlotinib, gefitinib and afatinib) with the pharmacy costs of other immune check-point inhibitors (ICIs), such as nivolumab, pembrolizumab and atezolizumab, registered in other tumors (e.g., NSCLC, head and neck carcinoma and urological malignancies) and known as the most expensive new drugs in medical oncology ${ }^{[19-24]}$, as well as the costs of the reference elements in international markets, 18 karat $(\mathrm{K})$ gold and platinum. All TKIs have the highest cost per gram, with $€ 305.33$ for erlotinib, $€ 288.24$ for gefitinib, $€ 3292.50$ for afatinib and $€ 1816.00$ for osimertinib, with a $\Delta$ toward $18 \mathrm{~K}$ gold and platinum per gram of $€ 258.43$ and $€ 283.88$ for erlotinib, respectively; $€ 241.34$ and $€ 266.79$ for gefitinib, respectively; $€ 3245.60$ and $€ 3271.05$ for afatinib, respectively; and $€ 1769.10$ and $€ 1794.55$ for osimertinib, respectively. This leads us to think that ICIs are not the most expensive targeted agents, but there are other more expensive ones. Thus, there is no doubt that data on osimertinib are good in daily clinical practice ${ }^{[1,13]}$, but a reduction in pharmacological costs is mandatory if we want to consider TKIs (in particular, osimertinib) more advantageous in terms of cost-effectiveness.

In conclusion, based on ICER, osimertinib is more cost-effective than the other TKIs (erlotinib, gefitinib and afatinib) in patients with activating EGFR mutations in first-line treatment for advanced NSCLC. The data on osimertinib are good in daily clinical practice (also confirmed by the high grade of clinical benefit on ESMO scale $\left.{ }^{[3]}\right)$, but a reduction in pharmacological costs is mandatory if we want to consider osimertinib more cost-effective in first-line treatment for EGFR-mutated advanced NSCLC.

\section{DECLARATIONS}

\section{Authors' contributions}

Conception and design, acquisition of data, or analysis and interpretation of data: Giuliani J, Bonetti A

Drafting the article and revising it critically for important intellectual content: Giuliani J, Bonetti A

Final approval of the version to be published: Giuliani J, Bonetti A

Each author contributed equally.

\section{Availability of data and materials}

Not applicable.

\section{Financial support and sponsorship}

None.

\section{Conflicts of interest}

The authors have no relevant affiliations or financial involvement with any organization or entity with a financial interest in or financial conflict with the subject matter or materials discussed in the manuscript. This includes employment, consultancies, honoraria, stock ownership or options, expert testimony, grants or patents received or pending, or royalties.

\section{Ethical approval and consent to participate \\ Not applicable.}

\section{Consent for publication}

Not applicable. 


\section{Copyright}

(C) The Author(s) 2021.

\section{REFERENCES}

1. Takeda M, Nakagawa K. First- and second-generation EGFR-TKIs are all replaced to osimertinib in chemo-naive EGFR mutationpositive non-small cell lung cancer? Int J Mol Sci 2019;20:146. DOI PubMed PMC

2. Giuliani J, Bonetti A. The economic impact of biosimilars in oncology and hematology: the case of Trastuzumab and Rituximab. Anticancer Res 2019;39:3971-3. DOI PubMed

3. Aguilar-Serra J, Gimeno-Ballester V, Pastor-Clerigues A, et al. Osimertinib in first-line treatment of advanced EGFR-mutated nonsmall-cell lung cancer: a cost-effectiveness analysis. J Comp Eff Res 2019;8:853-63. DOI PubMed

4. Cherny NI, Sullivan R, Dafni U, et al. A standardised, generic, validated approach to stratify the magnitude of clinical benefit that can be anticipated from anti-cancer therapies: the European Society for Medical Oncology Magnitude of Clinical Benefit Scale (ESMOMCBS). Ann Oncol 2015;26:1547-73. DOI PubMed

5. Giuliani J, Bonetti A. Which grade is of clinical benefit in the randomised controlled trials? Eur J Cancer 2018;104:233-5. DOI PubMed

6. Zhou C, Wu YL, Chen G, et al. Erlotinib versus chemotherapy as first-line treatment for patients with advanced EGFR mutationpositive non-small-cell lung cancer (OPTIMAL, CTONG-0802): a multicentre, open-label, randomised, phase 3 study. Lancet Oncol 2011;12:735-42. DOI PubMed

7. Rosell R, Carcereny E, Gervais R, et al; Spanish Lung Cancer Group in collaboration with Groupe Français de Pneumo-Cancérologie and Associazione Italiana Oncologia Toracica. Erlotinib versus standard chemotherapy as first-line treatment for European patients with advanced EGFR mutation-positive non-small-cell lung cancer (EURTAC): a multicentre, open-label, randomised phase 3 trial. Lancet Oncol 2012;13:239-46. DOI PubMed

8. Mok TS, Wu YL, Thongprasert S, et al. Gefitinib or carboplatin-paclitaxel in pulmonary adenocarcinoma. $N$ Engl J Med 2009;361:947-57. DOI PubMed

9. Maemondo M, Inoue A, Kobayashi K, et al; North-East Japan Study Group. Gefitinib or chemotherapy for non-small-cell lung cancer with mutated EGFR. N Engl J Med 2010;362:2380-8. DOI PubMed

10. Mitsudomi T, Morita S, Yatabe Y, et al; West Japan Oncology Group. Gefitinib versus cisplatin plus docetaxel in patients with nonsmall-cell lung cancer harbouring mutations of the epidermal growth factor receptor (WJTOG3405): an open label, randomised phase 3 trial. Lancet Oncol 2010;11:121-8. DOI PubMed

11. Han JY, Park K, Kim SW, et al. First-SIGNAL: first-line single-agent iressa versus gemcitabine and cisplatin trial in never-smokers with adenocarcinoma of the lung. J Clin Oncol 2012;30:1122-8. DOI PubMed

12. Sequist LV, Yang JC, Yamamoto N, et al. Phase III study of afatinib or cisplatin plus pemetrexed in patients with metastatic lung adenocarcinoma with EGFR mutations. J Clin Oncol 2013;31:3327-34. DOI PubMed

13. Wu Y, Zhou C, Hu CP, et al. Afatinib versus cisplatin plus gemcitabine for first-line treatment of Asian patients with advanced nonsmall-cell lung cancer harbouring EGFR mutations (LUX-Lung 6): an open-label, randomised phase 3 trial. Lancet Oncol 2014;15:213-22. DOI PubMed

14. Soria JC, Ohe Y, Vansteenkiste J, et al; FLAURA Investigators. Osimertinib in untreated EGFR-mutated advanced non-small-cell lung cancer. N Engl J Med 2018;378:113-25. DOI PubMed

15. Fukuoka M, Wu YL, Thongprasert S, et al. Biomarker analyses and final overall survival results from a phase III, Randomized, openlabel, first-line study of gefitinib versus carboplatin/paclitaxel in clinically selected patients with advanced non-small-cell lung cancer in Asia (IPASS). J Clin Oncol 2011;29:2866-74. DOI PubMed

16. Ramalingam SS, Vansteenkiste J, Planchard D, et al; FLAURA Investigators. Overall survival with Osimertinib in untreated, EGFRmutated advanced NSCLC. N Engl J Med 2020;382:41-50. DOI PubMed

17. Hofmarcher T, Lindgren P, Wilking N, Jönsson B. The cost of cancer in Europe 2018. Eur J Cancer 2020;129:41-9. DOI PubMed

18. Azimi NA, Welch HG. The effectiveness of cost-effectiveness analysis in containing costs. J Gen Intern Med 1998;13:664. DOI PubMed PMC

19. Giuliani J, Bonetti A. Financial toxicity and non-small cell lung cancer treatment: the optimization in the choice of immune check point inhibitors. Anticancer Res 2019;39:3961-5. DOI PubMed

20. Giuliani J, Bonetti A. Immunotherapy in first-line for advanced non-small cell lung cancer: a cost-effective choice? Recenti Prog Med 2019;110:138-43. DOI PubMed

21. Giuliani J, Bonetti A. Immune-checkpoint inhibitors in head and neck squamous cell carcinoma: cost-efficacy in second-line treatment based on programmed death-ligand 1 (PD-L1) level. Oral Oncol 2019;97:143-5. DOI PubMed

22. Giuliani J, Bonetti A. Nivolumab in second-line treatment for advanced non-small-cell lung cancer with squamous-cell histology: a perspective based on pharmacologic costs. Clin Lung Cancer 2017;18:e363-5. DOI PubMed

23. Giuliani J, Bonetti A. Nivolumab is a cost-effective second-line treatment for metastatic renal-cell carcinoma. Clin Genitourin Cancer 2018;16:e557-62. DOI PubMed

24. Giuliani J, Albanese V, Ponturo G, Bonetti A. Economic sustainability of nivolumab at flat dose for second-line treatment of metastatic non-small cell lung cancer in real life. J Oncol Pharm Pract 2019;25:2059-60. DOI PubMed 